\title{
COMMENTARY
}

\section{A RESPONSE TO PROFESSOR RESNICK: WILL THIS VEHICLE PASS INSPECTION?}

\author{
S. ELIZABETH GIBSON ${ }^{\dagger}$
}

\section{INTRODUCTION}

Raising the topic of bankruptcy in the midst of a symposium on any nonbankruptcy topic tends to put a damper on things. It is a little bit like trying to sell life insurance at a wedding: Why spoil the fun of discussing intellectual property law, family law, environmental law, or you-name-it by raising the specter of a distressed debtor's resort to that murky realm of the federal courts? Fortunately, the organizers of this Symposium wisely chose to include among the topics for discussion the consideration of bankruptcy as a tool for resolving mass torts. Perhaps its inclusion comes more naturally to this Symposium than to others, since a discussion of mass torts necessarily devotes itself to a crisis situation. Moreover, given the increasing number of companies that have pursued a bankruptcy reorganization solution to their mass tort problems, ${ }^{1}$ a symposium focusing on the current realities presented by mass tort litigation and seeking better means of resolving such cases could not reasonably omit consideration of the topic. ${ }^{2}$

Professor Resnick makes a good case for accepting bankruptcy as

$\dagger$ Burton Craige Professor of Law, University of North Carolina at Chapel Hill. I gratefully acknowledge the invaluable research and collaborative assistance provided by Matthew C. Stiegler.

${ }^{1}$ See, e.g., Lindsey v. O'Brien, Tanski, Tanzer \& Young Health Care Providers of Conn. (In re Dow Corning Corp.), 86 F.3d 482, 485 (6th Cir. 1996); In re UNR Indus., Inc., 20 F.3d 766, 767-68 (7th Cir. 1994); In re Amatex Corp., 755 F.2d 1034, 1035 (3d Cir. 1985); In re Eagle-Picher Indus., Inc., 203 B.R. 256 (S.D. Ohio 1996); In re A.H. Robins Co., 88 B.R. 742, 743-45 (E.D. Va. 1988), aff'd, 880 F.2d 694, 696-97 (4th Gir. 1989); In re Johns-Manville Corp., 68 B.R. 618, 621 (Bankr. S.D.N.Y. 1986).

${ }^{2}$ Cf. ADVISORY COMM. ON GTVIL RULES AND WORKING GROUP ON MASS TORTS, REPORT ON MASS TORT LITIGATION 58-60 (Feb. 15, 1999) [hereinafter REPORT ON MASS TORT LITIGATION] (discussing possible bankruptcy solutions to mass tort problem).

"Unless otherwise indicated, I use the term "bankruptcy" throughout this com- 
an appropriate vehicle for resolving what he calls "enterprisethreatening" mass tort liability. ${ }^{4}$ Among other things, he points out the procedural and jurisdictional advantages of bankruptcy that permit the consolidation and binding resolution of all pending and future tort claims against the debtor. He then advocates statutory changes to clarify existing uncertainties concerning bankruptcy's treatment of mass tort claims and to bolster bankruptcy courts' authority to achieve a "lasting and global peace" of a corporate debtor's mass tort liability. ${ }^{5}$ I am in basic agreement with these two main points of Professor Resnick's article. I agree that bankruptcy is an appropriate tool for resolving mass tort claims asserted against certain defendants and that improvements should be sought to make bankruptcy a more effective mass tort resolution method. I fear, however, that Professor Resnick has overstated the case for bankruptcy in certain respects, and so I address constitutional concerns raised in certain mass tort contexts which a bankruptcy resolution may not be able to ignore.

Even those who have not heretofore embraced the idea that bankruptcy is an appropriate vehicle for resolving mass torts may now be forced to consider such a possibility, given the obstacles that the Supreme Court has recently placed in the way of two other collective resolution devices. The Court's first product liability mass tort decision, Amchem Products, Inc. v. Windsor, ${ }^{6}$ rejected a Rule 23(b) (3) class certification that was sought to achieve a global settlement affecting "hundreds of thousands, perhaps millions, of individuals" either currently or possibly in the future possessing asbestos-related claims against one or more of twenty companies. ${ }^{7}$ In so ruling, the Court identified certification problems in that case that may exist for many attempted mass tort settlements ${ }^{8}$ and for which the necessary solutions

mentary to refer to bankruptcy reorganizations under Chapter 11 of the Bankruptcy Code, 11 U.S.C. $\$ \S 1101-1146$ (1994).

${ }^{4}$ Alan N. Resnick, Bankruptcy as a Vehicle for Resolving Enterprise-Threatening Mass Tort Liability, 148 U. PA. L. REV. 2045 (2000).

Id. at 2067.

${ }^{6} 521$ U.S. 591 (1997).

7 Id. at 597.

${ }^{8}$ See id. at 624 (holding that Rule 23(b)(3)'s requirement that "[common] questions of law or fact predominate" was not satisfied due to the overarching significance of questions "peculiar to the several categories of class members, and to individuals within each category"); $i d$. at 626-27 (holding that Rule 23(a)(4)'s adequacy of representation requirement was not met due to lack of alignment of class members' interests and absence of "structural assurance of fair and adequate representation for the diverse groups and individuals affected"); id. at 628 (questioning whether constitutionally adequate notice "could ever be given to legions so unselfconscious and amor- 
are likely to make Rule 23(b) (3) settlements less attractive as a mass tort remedy. ${ }^{9}$ More recently, in Ortiz v. Fibreboard Corp., ${ }^{10}$ the Court reversed the certification of a Rule 23(b) (1)(B) class action settlement based on the class's failure to satisfy requirements that the Court derived from a historically based model ${ }^{11}$ of limited fund class actions. ${ }^{12}$ The Court not only imposed requirements for limited fund class actions that may be difficult to meet, ${ }^{13}$ but also pointedly questioned on several occasions, without resolving, whether a mandatory Rule 23(b) (1) (B) class action may ever be appropriately certified in the case of a mass tort. ${ }^{14}$ While Amchem and Ortiz may not sound the death

phous" as the class members who had not manifested any asbestos-related injuries and their future spouses and children).

${ }^{9}$ See REPORT ON MASS TORT LITIGATION, supra note 2, at 41 (" [C]ertifying and settling a large class action under Rule 23(b)(3) for global peace may be more difficult after Amchem and may be unachievable for future claimants."); John C. Coffee, Jr., Conflicts, Consent, and Allocation After Amchem Products-Or, Why Attorneys Still Need Consent to Give Away Their Clients' Money, 84 VA. L. REV. 1541, 1552-53 (1998) (discussing one possible reading of Amchem as requiring the "balkaniz[ation of] the class into an unmanageable assortment of small subclasses that cannot easily act in concert"); Eric D. Green, What Will We Do When Adjudication Ends? We'll Settle in Bunches: Bringing Rule 23 into the Twenty-First Century, 44 UCLA L. REV. 1773, 1778 (1997) ("[I]t is apparent that few, if any, mass tort classes (especially those involving exposure-only victims), could meet the [Amchem] majority's interpretation of Rule 23(b) (3)'s predominance test or Rule 23(a) (4)'s adequacy of representation test, for either class action settlement or trial.").

10 527 U.S. 815, 119 S. Ct. 2295 (1999).

"See id. at 2309-12 (identifying the characteristics of traditional limited fund suits); $i d$. at 2313 (noting that "the greater the leniency in departing from the historical limited fund model, the greater the likelihood of abuse" and "[t]he prudent course, therefore, is to presume that... the object [of Rule 23(b)(I)(B)] was to stay close to the historical model").

${ }^{12}$ The Court held that a limited fund mass tort settlement class must satisfy the following requirements to be certified, and that the class before it had failed to do so:

[I]t would be essential that the fund be shown to be limited independently of the agreement of the parties to the action, and equally essential under Rule 23(a) and (b) (1)(B) that the class include all those with claims unsatisfied at the time of the settlement negotiations, with intraclass conflicts addressed by recognizing independently represented subclasses.

Id. at 2323.

${ }^{19}$ See Matthew C. Stiegler, Note, Ortiz and the Future of Limited Fund Settlement Class Actions in Mass Tort Litigation, 78 N.C. L. REV. 856, 900 (2000) ("Ortiz has made limited fund class certification substantially, perhaps prohibitively, more difficult and uncertain.").

${ }^{11}$ See Ortiz, 119 S. Ct. at 2312 ("[W]e cannot... decide the ultimate question whether settlements of multitudes of related tort actions are amenable to mandatory class treatment ...."); id. at 2314 ("We do not, it is true, decide the ultimate question whether Rule 23(b)(1)(B) may ever be used to aggregate individual tort claims." (citation omitted)); id. at 2323 ("In sum, the applicability of Rule 23(b)(1)(B) to a fund and plan purporting to liquidate actual and potential tort claims is subject to question 
knell for mass tort class action settlements, ${ }^{15}$ the decisions certainly increase the difficulty of getting either type of class action certified by a district court and ultimately approved on appeal. ${ }^{16}$ It is to be expected, therefore, that parties seeking a global resolution of mass tort litigation may look elsewhere for a solution. ${ }^{17}$

Bankruptcy provides such a possible solution-at least until the Supreme Court decides to take and resolve a mass tort case that raises the issue whether bankruptcy may be used as a global resolution vehicle. $^{18}$ Companies overwhelmed by the costs of defending and satisfy-

...."); id. (emphasizing that in holding the settlement class invalid for failure to comport with the attributes of limited fund class actions, the Court "[a]ssum[ed] arguendo that a mandatory, limited fund rationale could under some circumstances be applied to a settlement class of tort claimants").

${ }^{15}$ See id. at 2322 ("[W]e have not ruled out the possibility under the present Rule of a mandatory class to deal with mass tort litigation on a limited fund rationale ...."); Coffee, supra note 9, at 1559 ("[T] here is a variety of feasible alternatives by which Amchem Products might be implemented. . . Amchem Products will in time require fairer rules, but the inquiry has only begun as how to best implement its holdings and its philosophy.").

${ }^{16}$ See, for example, Wish v. Interneuron Pharmaceuticals, Inc. (In re Diet Drugs (Phentermine, Fenfluramine, Dexfenfluramine) Prods. Liab. Litig.), No. MDL 1203, CIV.A.98-20594, 1999 WL 782560 (E.D. Pa. Sept. 27, 1999), in which the court stated:

While this court does not read Ortiz as a bar to limited fund class certification in all mass tort cases, Ortiz does counsel against those -class certifications which would deprive the class of the protections available under the traditional model. For that reason, the court denies the motion for class certification.

Id. at *I4. See, e.g., Walker v. Liggett Group, Inc., 175 F.R.D. 226, 233 (S.D.W. Va. 1997) ("Intervenor... has demonstrated adequately why certification, under either Rules 23(b) (1) (B) or (b) (3) cannot occur on these facts after Amchem. Accordingly, the Court (1) ... WTTHDRAWS its preliminary approval and certification of the settlement and settlement class; and (2) DENIES Plaintiffs' motion for class certification." (emphasis omitted)).

${ }^{17}$ See, e.g., Richard B. Schmitt \& Laura Johannes, Judge Rejects Intermeuron's Proposed Class-Action Settlement Over Diet Pill, WALL ST. J., Sept. 28, 1999, at B15 (speculating about possible bankruptcy filing by diet pill manufacturer after district court rejection of its proposed limited fund class action settlement).

${ }_{18}$ To date, the Supreme Court has not granted review in a mass tort bankruptcy case. See, e.g., Official Comm. of Tort Claimants v. Dow Corning Corp., 522 U.S. 977 (1997) (denying certiorari in breast implant bankruptcy); Official Comm. of Tort Claimants v. Dow Corning Corp., 519 U.S. 1071 (1997) (same); UNARCO Bloomington Factory Workers v. UNR Indus., Inc., 513 U.S. 999 (1994) (denying certiorari in asbestos bankruptcy); Menard-Sanford v. A.H. Robins Co., 493 U.S. 959 (1989) (denying certiorari in Dalkon Shield bankruptcy). Furthermore, significant procedural obstacles may stand in the way of Supreme Court review of the confirmation of a mass tort bankruptcy reorganization plan. By the time a challenge to a plan would be able to work its way up to the Supreme Court, it is likely that the plan would have been implemented to such a degree that review would be impracticable or futile. See, e.g., In re UNR Indus., Inc., 20 F.3d 766, 771 (7th Cir. 1994) (affirming district court's dismissal of appeal because, although the appeal was not legally moot, the plan's trust provisions 
ing the claims of thousands of tort claimants have in the past and will continue in the future to seek bankruptcy relief. ${ }^{19}$ Accordingly, whether or not bankruptcy is the preferred solution, attention needs to be paid to how it can be made more effective as a resolution vehicle for mass torts, and one that is constitutionally sound in all respects.

\section{ADVANTAGES OF BANKRUPTCY FOR RESOLVING MASS TORTS}

Professor Resnick has discussed a number of features of the bankruptcy system that make it an appropriate vehicle for resolving the mass tort litigation facing a bankruptcy debtor. The chief advantage is that bankruptcy, because it demands an all-encompassing financial solution, provides the best conceptual fit for the global resolution of enterprise-threatening mass tort liability. When a company faces massive tort liability that threatens the viability of the company, it is not just a problem for the tort claimants and the company's management. It is a problem affecting all who have a financial relationship with the company, including other creditors, shareholders, employees, customers, suppliers, officers, and directors. As Professor Resnick correctly points out, bankruptcy is the only resolution mechanism that makes the holders of all of those claims and interests come to the table and thereby come to grips with the problem facing the company. By staying other means of collecting debts and receiving property from the debtor, bankruptcy consolidates all financial claims against the debtor-not just those based on tort law-and then allows the various constituencies to participate in attempting to arrive at an equitable solution for all concerned parties. ${ }^{20}$

Bankruptcy's all-inclusive approach stands in contrast to the resolution of mass torts by means of limited fund class action settlements. ${ }^{21}$

were too far implemented to be disturbed); Rochman v. Northeast Utils. Serv. Group (In re Public Serv. Co. of N.H.), 963 F.2d 469, 476 (1st Cir. 1992) (dismissing appeal from plan confirmation on the ground that "the absence of a stay pending the appeal of the order confirming the reorganization plan permitted its implementation to so substantial an extent as to leave the court powerless to grant fair and effective relief").

${ }^{19}$ See, e.g., supra note 1 (listing cases of mass tort defendants seeking bankruptcy relief).

${ }^{20}$ See THOMAS H. JACKSON, THE LOGIC AND LIMITS OF BANKRUPTCY LAW 17 (1986) (explaining that bankruptcy is both collective and compulsory and stating that it "provides a way to override the creditors' pursuit of their own remedies and to make them work together"); GHARIES JORDAN TABB, THE LAW OF BANKRUPTCY 5 (1997) (describing bankruptcy as "a compulsory collective remedy"); $i d$. at 8 (noting that a "chapter 11 bankruptcy reorganization contains both a stay provision ... and a rule binding dissenters to the terms of the plan agreed to by the bulk of creditors").

${ }^{21}$ The contrast with Rule 23(b) (3) class action settlements is even more pro- 
The theory underlying the certification under Rule 23(b)(1)(B) of a mandatory class of tort claimants is that without such consolidation those who are among the first to sue and recover will deplete the company's assets, leaving nothing for those who seek recovery at a later time. ${ }^{22}$ Thus, in order to prevent the impairment of the latecomers' interests, all potential tort claimants are brought together in one proceeding, and the limited assets that the defendant company offers are divided equitably among them. ${ }^{23}$

The problem, however, with this theory is that if the allegedly insufficient fund is the company itself, rather than a finite fund to which only a discrete group has a claim, ${ }^{24}$ then the tort claimants are not the only ones competing for the scarce resources. All of the unsecured creditors have a claim to the unencumbered assets-and the shareholders to any remaining balance-and likewise all should be forced, in Professor Resnick's words, to "share the pain. "25 Limited fund class action settlements of mass torts, however, do not operate in this man-

nounced, since potential members of the class are allowed to opt out in that type of class action. See FED. R. Crv. P. 23(c)(2)-(3) (providing that potential members of a 23(b) (3) class may request exclusion and that those who do so will not be bound by the judgment). Thus, it is likely that not even all tort claimants will be included within the class action resolution.

${ }_{22}$ See, e.g., Fanning v. Acromed Corp. (In re Orthopedic Bone Screw Prods. Liab. Litig.), 176 F.R.D. 158, 177 (E.D. Pa. 1997) ("AcroMed's net assets and insurance coverage are vastly insufficient to satisfy the many claims against them. Additionally, ... [a]fter incurring ... defense costs, AcroMed would have had little or no ability to pay settlements or judgments to plaintiffs in individual cases."); Butler v. Mentor Corp. (In re Silicone Gel Breast Implant Prods. Liab. Litig.), Nos. CV 93-P-11433-S, CV 92-P-10000-S, MDL No. 926, 1993 WL 795477, at *5 (N.D. Ala. June 2, 1993) (basing preliminary certification decision on the "risk that defense costs, individual settlements, or a few judgments would exhaust the Mentor Defendants' assets before other claimants, with similar claims, had an opportunity to be heard").

${ }^{23}$ See Orthopedic Bome Screw, 176 F.R.D. at 177 ("This settlement shuts off AcroMed's defense cost flow and places all claimants on the same plane, at the same time, with respect to AcroMed's financial capacity to respond to all of the claims, leaving each claimant [']s share to be determined by traditional application of equitable distribution standards."); Silicone Gel Breast Implant, 1993 WL 795477, at *5 ("[T]he capture of these assets in the proposed settlement for equitable distribution to all class members appears to be a fairer and superior alternative to the potential exhaustion of these assets in continued litigation ..." ). But see Ortiz v. Fibreboard Corp., 527 U.S. 815, 119 S. Ct. 2295, 2313 (1999) (" $[\mathrm{I}] \mathrm{t}$ is clear that the Advisory Committee did not contemplate that the mandatory class action codified in subdivision (b) (1) (B) would be used to aggregate unliquidated tort claims on a limited fund rationale.").

${ }_{24}$ See Ortiz, 119 S. Ct. at 2309 (noting that among "classic" limited fund class actions are suits by claimants to trust assets, bank accounts, and insurance proceeds).

${ }^{25}$ See Richard L. Marcus, They Can't Do That, Can They? Tort Reform Via Rule 23, 80 CORNEIL L. REV. 858, 880 (1995) ("[T] he limited fund theory would call for the inclusion of all claimants, whatever the source of their claims."). 
ner. Only the tort claims are compromised; the claims of other unsecured creditors and the interests of shareholders remain unaffected. ${ }^{26}$

There may well be situations where it is fair to place the burden of compromise only on the tort claimants when a limited fund class action settlement is approved. If the defendant's tort liability is as yet scientifically unproven and still vigorously disputed, it may in fact be the case that the tort claimants are receiving more under the settlement than they would turn out to be entitled to receive if the claims were litigated, even if they are receiving only a percentage of the amount they initially claimed. ${ }^{27}$ Thus, it can be argued that the tort claimants are not being treated inequitably in relation to the commercial creditors. Even when liability is well established, a justification for paying commercial creditors in full while the tort claimants are required to share a limited fund may be that full payment of such creditors is necessary for the continued operation of the business, which in turn provides the basis for funding future pay-outs to the tort claimants. $^{28}$

The advantage bankruptcy has to offer, even when full payment of commercial claims may be in everyone's interest, is that all affected groups have an opportunity to negotiate and vote on the appropriate treatment of tort claimants, trade creditors, bond holders, shareholders, and the like. ${ }^{29}$ Thus the fairness of full payment of commercial

${ }^{26}$ See John C. Coffee, Jr., Class Wars: The Dilemma of the Mass Tort Class Action, 95 COLUM. L. REV. 1343, 1458-59 (1995) (criticizing limited fund class action settlements, pursuant to which "stock values soar, while tort creditors are either scaled back or forced to rely on thinly funded or unspecified settlement funds"); Marcus, supra note 25 , at 880 (emphasizing that limited fund class actions do not adjust the claims of all creditors to the defendant's limited assets).

${ }^{27}$ See Marcus, supra note 25, at 879 ("Plaintiff lawyers are notoriously and understandably generous in their prayers for relief, and these should not be taken as reliable indicators of probable recovery.").

23 This was the rationale of the district court in Orthopedic Bone Screw, 176 F.R.D. at 177. In approving a Rule 23(b)(1)(B) class settlement, the court explained that the settlement was to be funded by "an outside infusion of $\$ 100$ million of borrowed funds not otherwise available except for the terms of the settlement." Id. The court further noted that " $[w]$ ithout this infusion, the settlement cannot be accomplished and without the settlement, AcroMed will consume itself by exhausting all of its resources including its traditional borrowing potential." Id. Continued operation of the company was therefore necessary to repay the loan taken out to fund the settlement to the tort claimants.

${ }^{29}$ See 11 U.S.C. $\$ 1103$ (c)(3) (1994) (authorizing creditors' committees to "participate in the formulation of a plan [and] advise those represented by such committee of such committee's determinations as to any plan formulated"); id. $\$ 1126$ (a) ("The holder of a claim or interest allowed under section 502 of this title may accept or reject a plan."). 
creditors is not just assumed or accepted unquestioningly, as it is in the case of limited fund class action settlements. If such treatment is provided for by a bankruptcy reorganization plan, it must either be accepted by all classes of creditors and equity security holders, or substantive protections for non-accepting classes must be satisfied. ${ }^{30}$

Professor Resnick also points out the procedural advantages that bankruptcy offers for aggregating mass tort claims against the bankruptcy debtor in a single forum and then for arriving at a global and binding resolution of them. Among the features of bankruptcy that he discusses are the automatic stay, the grant of exclusive jurisdiction over the debtor's property, nationwide service of process, and the bankruptcy court's authority to determine where personal injury and wrongful death tort litigation will take place. ${ }^{31}$ These features of bankruptcy are essential components of a system designed to achieve a collective resolution of an ailing debtor's financial liabilities; one court is able to bring a halt to individual collection efforts and to oversee the orderly liquidation or reorganization of the debtor for the benefit of all creditors. ${ }^{32}$ These same procedures and grants of authority thus lend themselves naturally to the resolution of a large group of tort claims asserted against a company. ${ }^{33}$ Indeed, the value of these procedural tools for the resolution of mass torts is borne out

${ }^{\text {so }}$ See Keene Corp. v. Fiorelli (In re Joint E. \& S. Dist. Asbestos Litig.), 14 F.3d 726, 732 (2d Cir. 1993) ("[C]lass members in [class action] cases such as this would have no say in the conduct of the court-appointed class representatives and, unlike creditors in bankruptcy, are not able to vote on a settlement. For them, it would be 'cram-down' from start to finish." (citation omitted)).

${ }^{31}$ See Resnick, supra note 4, Part I.B (discussing the advantages of nationwide jurisdiction, automatic stay, and other procedures when dealing with mass torts).

${ }^{32}$ As one commentator has stated:

This collective approach, when applied to the bankruptcy system, creates a structure that precludes the creditors from individually chasing the debtor's treasure (the available assets). Instead, the creditors work together to both preserve and enhance the treasure and cut back on the costs of trying to recover a piece of it. The loss from the disaster (debtor nonpayment) is then shared among the creditors.

KAREN GROSS, FAILURE AND FORGIVENESS: REBALANCING THE BANKRUPTCY SYSTEM 137 (1997). See 3 COLIIER ON BANKRUPTCY I 362.03[2] (15th ed. 1999) ("Without the stay, the debtor's assets might well be dismembered, and its business destroyed, before the debtor has an opportunity to put forward a plan for future operations.... The stay prevents this piecemeal liquidation, offering the chance to maximize the value of the business.").

${ }^{33}$ See United States Lines, Inc. v. American S.S. Owners Mutual Protection \& Indem. Ass'n (In re United States Lines, Inc.), 197 F.3d 631, 641 (2d Cir. 1999) ("[A]s we have previously pointed out, the bankruptcy court is the preferable venue in which to handle mass tort actions involving claims against an insolvent debtor." (citing Joint $E$. E' S. Dist. Asbestos, 14 F.3d at 732)). 
by the extent to which the attempt has been made to incorporate similar procedures into mass tort class actions, effectively turning them into "designer bankruptcies. "\$4

If bankruptcy provides such an appropriate theoretical and procedural framework for addressing the situation facing a company whose viability is threatened by mass tort litigation, one might wonder why it has not become the mass tort solution of choice for such companies. Several practical obstacles stand in the way of bankruptcy's becoming the darling of the mass tort world. Generally, lawyers other than the ones who are engaged in litigating mass torts handle bankruptcies, ${ }^{35}$ and, as a general rule, judges other than those who handle mass tort litigation preside over bankruptcy cases. ${ }^{36}$ While these rules are not invariably true, ${ }^{37}$ they are true frequently enough to create a cultural divide that tort lawyers must traverse if a bankruptcy solution is sought. ${ }^{38}$ Perhaps an even greater deterrent to seeking a bankruptcy solution is the risk of displacement faced by those in a company who would be the ones generally to make the decision to file for bankruptcy. In cases in which the value of the mass tort claims truly appears to exceed the value of the company, existing management is faced with the very real possibility not only that they will lose their

$\mathbf{M}$

Indeed, the [class action] process contemplated by Keene mirrors a bankruptcy proceeding. The finding of a limited fund corresponds to a finding of insolvency. The preliminary injunction serves much the same function as the automatic stay under Section 362(a) of the Bankruptcy Code. The class representatives correspond to creditors' committees in Chapter 11 proceedings. The proposed mandatory class settlement mirrors a reorganization plan and 'cram-down,' followed by a discharge.

Joint E. E' S. Dist. Asbestos, 14 F.3d at 732 (citations omitted); see also Henry Paul Monaghan, Antisuit Injunctions and Preclusion Against Absent Nontesident Class Members, 98 ColUM. L. REv. 1148, 1164 (1998) (describing Rule 23 (b)(1)(B) mass tort class actions as the "functional equivalent to bankruptcy").

${ }^{35}$ See, e.g., REPORT ON MASS TORT LITIGATION, supra note 2, app. E at 34 (noting hiring of bankruptcy specialist as counsel to claimants' committee); RICHARD B. SOBOL, BENDING THE LAW 69, 74 (1991) (same).

${ }^{36}$ See 28 U.S.C. § 157(a) (1994) (authorizing district courts to refer all bankruptcy cases to bankruptcy courts).

${ }^{97}$ See, e.g., id. \$ 157(d) (authorizing district court "for cause shown" to withdraw a case referred to bankruptcy court); Ackles v. A.H. Robins Co. (In re A.H. Robins Co.) 59 B.R. 99, 105-07 (E.D. Va. 1986), aff'd sub nom. Beard v. A.H. Robins Co., 828 F.2d 1029, 1031 (4th Cir. 1987) (withdrawing reference to bankruptcy court of most matters in Dalkon Shield bankruptcy).

${ }^{33}$ See, e.g., SOBOL, supra note 35 , at 73 (observing that plaintiffs' attorneys in the Dalkon Shield litigation were suspicious and felt outside their "natural habitat" when the manufacturer filed for bankruptcy). 
jobs, ${ }^{39}$ but also that the tort claimants will emerge from bankruptcy as the owners of the reorganized company. Taking a step that may cause the company to be turned over to its litigation adversaries is likely to be considered only as a last resort. ${ }^{40}$ Finally, even from the viewpoint of disinterested policymakers, bankruptcy has the disadvantage of taking a long time to arrive at a resolution, frequently four or more years to reorganize a company facing mass tort liability. ${ }^{41}$ The long pendency of the bankruptcy case in turn results in an even longer delay in making payments to tort victims ${ }^{42}$ and an ever escalating cost of achieving a resolution.

Some of these obstacles are the inevitable result of enterprisethreatening liability, but others are capable of being addressed through procedural reforms. ${ }^{43}$ In either event, the harsh reality is that

${ }^{39}$ See GrOSS, supra note 32, at 32 ("[M]anagers of large financially troubled companies are frequently replaced just before or during a large [bankruptcy] case."); Lynn M. LoPucki \& William C. Whitford, Comporate Governance in the Bankruptcy Reorganization of Large, Publicly Held Companies, 141 U. PA. L. REv. 669, 723 (1993) (finding that publicly held corporations undergoing Chapter 11 reorganizations experience a high rate of CEO turnover).

40 Cf. REPORT ON MASS TORT IITIGATION, supra note 2, app. E at 16 (noting debtor's determination to retain control of the reorganized corporation); SOBOL, supra note 35, at 201-04 (noting Company's endorsement of the reorganization plan that would enable management to retain control).

41 See REPORT ON MASS TORT LITIGATION, supra note 2, app. C at 84-85 \& nn.453-54 (noting that long delays have been "a major criticism" of bankruptcy as a mass tort resolution tool).

${ }^{42}$ See, e.g., Georgene M. Vairo, Georgine, the Dalkon Shield Claimants Trust, and the Rhetoric of Mass Tort Claims Resolution, 31 LoY. L.A. L. REv. 79, 155 (1997) (noting that it took approximately nine years after the Robins plan was consummated and the trust received full funding for all Dalkon Shield claims to be resolved).

13 Professor Resnick has identified a number of statutory gaps in the Bankruptcy Code that need to be addressed if bankruptcy is to operate more effectively and on a firmer legal footing as a mass tort resolution device. I agree with many of the proposed solutions. For example, because bankruptcy has been, and will be, pursued by mass tort defendants that have sold products other than asbestos, see, e.g., Lindsey v. O'Brien, Tanski, Tanzer \& Young Health Care Providers of Conn. (In re Dow Corning Corp.) 86 F.3d 482 (6th Cir. 1996) (breast implants); In re A.H. Robins Co., 88 B.R. 742 (E.D. Va. 1988), affd, 880 F.2d 694 (4th Cir. 1989) (birth control devices), the Bankruptcy Code needs to be amended to eliminate asbestos-specific mass tort authority and instead to provide generally for the resolution of mass torts, whatever the source of the claims may be. Likewise, the status in bankruptcy of future claimants needs to be statutorily clarified, although as I discuss below, due process considerations may limit how broadly the class of future claimants should be defined, see infra note 97 and accompanying text. Finally, I agree with Professor Resnick's suggestions for substantive amendments to the Bankruptcy Code that would allow the subordination of punitive damages in mass tort bankruptcy reorganizations, the preconfirmation payment of mass tort claimants' emergency medical expenses, and the protection of asset purchasers from successor liability. 
other options for collective resolution of mass tort claims may be disappearing, so bankruptcy, warts and all, may be a necessary choice for some defendants. Attention needs to be given, therefore, to possible constitutional objections to using bankruptcy to resolve all present and future tort claims.

\section{CONCERNS ABOUT BANKRUPTCY AS A MASS TORT VEHICLE}

Professor Resnick cites, as one of bankruptcy's advantages, its standard for classifying claims together that "is far less restrictive than the four threshold requirements applicable to class actions under Rule 23." ${ }^{\text {"4 }}$ As he points out, the Bankruptcy Code's only requirement for grouping claims together in one class is that they be "substantially similar, ${ }^{\not 15}$ a requirement that courts have generally interpreted as meaning that the claims have the same distribution rank against the same property of the debtor. ${ }^{46}$ In that sense, all nonpriority, unsubordinated, unsecured claims are substantially similar and are permitted to be grouped together in a single class in a reorganization plan. ${ }^{47}$

Because of this flexibility in classifying unsecured claims, reor-

"14 Resnick, supra note 4, at 2060.

1511 U.S.C. \$ 1122(a) (1994) (providing that "a plan may place a claim or interest in a particular class only if such claim or interest is substantially similar to the other claims or interests of such class").

${ }^{46}$ See, e.g., In re AOV Indus., Inc., 792 F.2d 1140, 1150 (D.C. Cir. 1986) ("[T] he focus of the classification is the legal character of the claim as it relates to the assets of the debtor"); 7 COLLIER ON BANKRUPTCY, supra note 32, I 1122.03[3] ("[T] he term 'substantially similar' must be construed to mean similar in legal character or effect as a claim against the debtor's assets or as an interest in the debtor."); id. I 1122.03[4] ("Claims of the same kind and the same rank involving the same property may be included within a single class." ); John C. Anderson, Classification of Claims and Interests in Reorganization Cases Under the New Bankrupty Code, 58 AM. BANKR. L.J. 99, 101 (1984) ("As a general rule, all creditors with equal rank and with claims against the same property are usually placed in the same class ...."). But see Teamsters Nat'l Freight Indus. Negotiating Comm. v. U.S. Truck Co. (In re U.S. Truck Co.) 800 F.2d 581, 58487 (6th Gir. 1986) (affirming district court's conclusion that, because of the union's unique noncreditor interests, its unsecured claim was not substantially similar to other unsecured claims).

17 See In re Eisenbarth, 77 B.R. 228, 236 (Bankr. D.N.D. 1987) ("An unsecured claim is simply that, an unsecured claim. No valid reason exists for treating the unsecured claims of [certain institutional creditors] different than the unsecured claims of the trade creditors."); Anderson, supra note 46, at 119 (stating that generally "the unsecured creditors will be placed in the same class and receive the same treatment"); Peter E. Meltzer, Disenfranchising the Dissenting Creditor Through Artificial Classification or Artificial Impaiment, 66 AM. BANKR. L.J. 281, 290 (1992) ("Unsecured claims will, generally speaking, comprise one class, whether trade, tort, publicly held debt or a deficiency of a secured creditor." (quoting 3 WILLIAM L. NORTON, JR., BANKRUPTCY LAW \& PRACTICE $\$ 60.05$, at 7 (1991))). 
ganization plans in mass tort bankruptcies frequently place all of the tort claims together in a single class, regardless of the nature of the injury, the existence of issues unique to certain claimants, the varying degrees of legal strength of the claims, or the extent to which injury has been manifested. ${ }^{48}$ If such a classification scheme satisfies not only statutory requirements but also passes constitutional muster, then Professor Resnick may be correct in suggesting that bankruptcy offers an advantage in its ability to consolidate claims. The concerns raised after Amchem and Ortiz about the possible need for an unwieldy number of class action subclasses of mass tort claimants ${ }^{49}$ could be alleviated by utilizing bankruptcy's one-class grouping. ${ }^{50}$

Before accepting the argument that bankruptcy offers an advantage in this regard, however, one must determine why bankruptcy is permitted greater flexibility in classification than class actions possess. Perhaps the answer is simply that Rule 23 imposes certain express requirements for class certification that the Bankruptcy Code just does not impose on Chapter 11 plan classification. For all class actions, "the claims ... of the representative parties [must be] typical of the claims ... of the class" ${ }^{51}$ and "the representative parties [must] fairly and adequately protect the interests of the class. ${ }^{352}$ For 23(b) (3) class actions, specifically, "the questions of law or fact common to the

${ }^{48}$ See, e.g., In re A.H. Robins Co., 880 F.2d at 697 (referring to the class of Dalkon Shield claimants as one "with so many various unliquidated personal injury claims which vary so much in the extent and nature of injury, medical evidence and causation factors" as to render it nearly impossible to provide specific estimates of recovery); UNARCO Bloomington Factory Workers v. UNR Indus., Inc., 124 B.R. 268, 271 (N.D. Ill. 1990) (describing class of asbestos claimants in UNR reorganization plan as including "asbestos victims who know they have claims against UNR .... [and] those who may have been exposed to UNR's asbestos products before the bankruptcy, before confirmation, or after confirmation, but do not yet have an injury or know they have an injury"); REPORT ON MASS TORT LITIGATION, supra note 2, app. E at 34 (describing class 17 of Eagle-Picher reorganization plan as consisting of "all present and future rights to payment for death, bodily injury, or other personal damages resulting from exposure to asbestos or asbestos-containing products, or from products containing lead chemicals, manufactured or distributed by the debtor prior to the bankruptcy petition date").

${ }^{49}$ See supra notes 6-16 and accompanying text (suggesting that sub-classes are necessary for a class involving all mass tort victims to be certified).

${ }^{50}$ See, e.g., In re Dow Corning Corp., 244 B.R. 634, 655-56 (Bankr. E.D. Mich. 1999) (rejecting argument that more valuable, multi-rupture breast implant claims are not substantially similar to single rupture claims and thus must be separately classified); id. at 658 ("[A]ll breast-implant claims, both domestic and foreign, are substantially similar.").
${ }^{51}$ FED. R. GIV. P. 23(a) (3).
${ }^{32}$ FED. R. GV. P. 23(a) (4). 
members of the class [must] predominate over any questions affecting only individual members. ${ }^{353}$ The Bankruptcy Code, by contrast, only requires substantial similarity. ${ }^{54}$ Stating the differences in the requirements, however, merely begs the question why typicality, adequacy of representation, and predominance are concerns of class actions and not also of bankruptcy. ${ }^{55}$

The Supreme Court's opinions in Amchem and Ortiz, while not models of clarity, do provide some insights into the basis for the Court's concerns about proper classification of mass tort claimants involved in class action settlements. In both cases, the Court's holding that the certification and approval of the class action settlement was invalid rested squarely on the Court's interpretation of Rule $23{ }^{56}$ To the extent that the decisions interpret Rule 23, they do not apply to questions about the proper classification of tort claimants in bankruptcy reorganization plans under the Bankruptcy Code.

Going beyond the actual holdings of Amchem and Ortiz, however, one sees suggestions of broader due process and fairness concerns animating the Court's reasoning. For example, in Amchem, Justice Ginsburg explained on several occasions that the certification requirements of Rule 23(a) and (b) are designed to focus the certifying court's attention on whether the proposed class is "sufficiently cohesive" to permit representational litigation, thus allowing a departure from the usual rule that only parties to a lawsuit may be bound by its judgment. ${ }^{57}$ In other words, because class actions constitute an excep-

33 FED. R. GT. P. 23(b) (3).

${ }^{54}$ See 11 U.S.C. \$ 1122(a) (1994) (providing that "a plan may place a claim or an interest in a particular class only if such claim is substantially similar to the other claims or interests of such class" (emphasis added)).

${ }^{35}$ See Edith H. Jones, Rough Justice in Mass Future Claims: Should Bankruptcy Courts Direct Tort Reform?, 76 TEX. L. REV. 1695, 1713 (1998) ("[O]ne must ask what unique bankruptcy standards warrant replacing the essential Rule 23 'class-qualifying criteria' of commonality, typicality, and adequacy of representation." (quoting Amchem Prods., Inc. v. Windsor, 521 U.S. 591, 621 (1997))).

${ }^{36}$ See Ortiz v. Fibreboard Corp., 527 U.S. 815, 119 S. Ct. 2295, 2322 (1999) ("The nub of our position is that we are bound to follow Rule 23 as we understood it upon its adoption, and that we are not free to alter it except through the process prescribed by Congress in the Rules Enabling Act."); Amchem, 521 U.S. at 628 ("[W] have concluded that the class in this case cannot satisfy [Rule 23's] requirements of common issue predominance and adequacy of representation ....").

${ }^{57}$ Amchem, 521 U.S. at 623 ("The Rule 23(b)(3) predominance inquiry tests whether proposed classes are sufficiently cohesive to warrant adjudication by representation."); see also id. at 621 ("Subdivisions (a) and (b) focus court attention on whether a proposed class has sufficient unity so that absent members can fairly be bound by decisions of class representatives."); $i d$. at $626 \mathrm{n} .20$ (noting the overlap of the adequacy of representation, commonality, and typicality requirements and explaining that they 
tion to the general due process requirement that everyone be afforded her own day in court, the rule makers imposed requirements, which the Court applies strictly, designed to confine the certification of classes to those situations in which there is a sufficient identity of interest between class members and their representatives that the class members' rights may be fairly adjudicated in their absence. ${ }^{58}$ Similarly, Ortiz reflects the Court's underlying concern about the due process implications of imposing a binding resolution of claims on absent parties without strict insistence on the absence of conflicts of interest between class members and those purporting to represent them. ${ }^{59}$

Amchem and Ortiz thus suggest that the Constitution, not just the current version of Rule 23, prohibits the certification of broadly defined settlement classes of tort claimants with varying and potentially conflicting interests. If so, the reasoning of these decisions would also seem to apply to classifications in bankruptcy. The Court in Ortiz, however, distinguished bankruptcy from the class action context then before it. After discussing the general rule that persons not joined as parties may not be bound by the results of a lawsuit, the Court cited (in addition to representational litigation) bankruptcy as an example of an exceptional situation involving a "special remedial scheme" that permissibly "foreclos[es] successive litigation by nonlitigants." Elsewhere in the opinion, the Court referred to the "protections for

all "serve as guideposts for determining whether... maintenance of a class action is economical and whether the named plaintiff's claim and the class claims are so interrelated that the interests of the class members will be fairly and adequately protected in their absence"" (quoting General Tel. Co. of Southwest v. Falcon, 457 U.S. 147, 157-58 n.13 (1982))).

${ }^{38}$ See Samuel Issacharoff, Class Action Conflicts, 30 U.C. DAvIS L. REv. 805, 805 (1997) (discussing the various ways in which class actions represent "a clear departure from the premise that no one should be bound to a judgment in personam absent the personal security offered by notice and a full opportunity to participate in the underlying litigation").

${ }_{59}$ See Ortiz, 119 S. Ct. at 2315 (discussing the "inherent tension between representative suits and the day-in-court ideal" and noting that the tension is increased in a mandatory class settlement because " $[t]$ he legal rights of absent class members ... are resolved regardless either of their consent, or, in a class with objectors, their express wish to the contrary"); see also Issacharoff, supra note 58, at 822 (discussing concerns about mandatory class settlements in which "there is no capacity to refuse courtappointed representation" and "the individual class member is presented with what purports to be a binding fait accompli, with the only recourse a likely futile objection at the fairness hearing required by Rule $23(\mathrm{e})$ ").

${ }^{60}$ Ortiz, 119 S. Ct. at 2315 (quoting Martin v. Wilks, 490 U.S. 755, 762 n.2, in which the Court noted that bankruptcy and probate are examples of "legal proceedings [that] may terminate pre-existing rights [of nonlitigants] if the scheme is otherwise consistent with due process"). 
creditors built into the Bankruptcy Code. ${ }^{.61}$ These protections are in apparent contrast to the lack of "structural assurance of fair and adequate representation for the diverse groups and individuals affected,"' which the Court found fatal to the settlement classes presented by both Ortiz and Amchem. ${ }^{62}$ Thus, the Court's view may be that bankruptcy differs from class actions in significant respects that render inapplicable the strict classification requirements that due process may otherwise require for class action certification. ${ }^{63}$

If bankruptcy is distinguishable, it must be because of the procedural and substantive protections it affords creditors-protections that are unavailable to absent class members when a class action is certified. In mass tort class actions, the Court's expressed concern is that the personal injury claims of class members are being compromised without their direct consent by persons designated to represent them. ${ }^{64}$ The only protection for class members, other than the opportunity in some cases to opt out ${ }^{65}$ and the requirement that the court approve the settlement, ${ }^{66}$ is the insistence that the representatives share and competently represent their interests. ${ }^{67}$ While bankruptcy

61

[I]t is worth noting that if limited fund certification is allowed in a situation where a company provides only a de minimis contribution to the ultimate settlement fund, the incentives such a resolution would provide to companies facing tort liability to engineer settlements similar to the one negotiated in this case would, in all likelihood, significantly undermine the protections for creditors built into the Bankruptcy Code.

Id. at 2321 n. 34 .

${ }_{62} I d$. at 2319 (quoting Amchem, 521 U.S. at 627).

"s It should be noted, however, that although the Court in Amchem distinguished limited fund class actions from the opt-out class action then before it, see 521 U.S. at $623 \mathrm{n} .19$, it later imposed similarly strict certification requirements on that type of class action, see Ortiz, 119 S. Ct. at 2319-21.

${ }^{64}$ See id. at 2314-15 (discussing due process concerns with respect to mandatory class action settlements); Amchem, 521 U.S. at 626-27 (discussing need for protection of absent class members' interests by means of representation for homogeneous subgroups).

${ }^{65}$ See FED. R. GTV. P. 23(c)(2)-(3) (providing for an opt-out right in the case of a Rule 23(b) (3) class action).

${ }^{65}$ See FED. R. CNV. P. 23(e) ("A class action shall not be dismissed or compromised without the approval of the court....").

${ }^{67}$ See Amchem, 521 U.S. at 626 n.20, which states:

The adequacy-of-representation requirement "tend[s] to merge" with the commonality and typicality criteria of Rule 23(a), which "serve as guideposts for determining ... whether the named plaintiff's claim and the class claims are so interrelated that the interests of the class members will be fairly and 
also permits some creditors to represent the interests of others, ${ }^{68}$ these representatives, by contrast, do not have the final say. An appointed creditors' committee is primarily a negotiating agent. ${ }^{69}$ Once a reorganization plan is devised, even one supported by the committee, it must be sent out for voting by the creditors and interest holders. ${ }^{70}$ Thus, each identifiable creditor whose claim is impaired is given the opportunity to express his or her approval or disapproval of the proposed resolution. ${ }^{71}$ Although the Bankruptcy Code does not require unanimity, ${ }^{72}$ it guarantees dissenting creditors in an accepting class a minimum level of payment. ${ }^{73}$ Furthermore, if the preference of a class

adequately protected in their absence." The adequacy heading also factors in competency and conflicts of class counsel.

Id. (quoting General Tel. Co. of Southwest v. Falcon, 457 U.S. 147, 157-58 n.13) (citation omitted). Moore's Federal Practice observes that:

This "adequacy of representation" requirement was designed to protect the due process rights of absent class members. ... Because the judgment in a class action has res judicata implications ... for the absent class members, due process requires that the interests of absent members be adequately represented by the class members who are parties to the action.

5 JaMes WM. MOORE ET AL, MOORE's Federal Practice $§ 23.25[1]$ (3d ed. 1996) (footnotes omitted).

${ }^{6}$ See 11 U.S.C. $\$ 1102$ (1994) (requiring that a United States trustee appoint an unsecured creditors' committee except in small business bankruptcy cases).

${ }^{69}$ See, e.g., DAVID G. EPSTEIN ET AL., BANKRUPTCY $\$ 10-11$ (1993) ("The principal role of the committee is to speak and negotiate for the larger group which it represents."); TABB, supra note 20 , at 67 ("The committee plays a particularly important role in the formulation and confirmation of a reorganization plan. The committee negotiates directly with the debtor ... over the terms of a plan on behalf of the class of creditors or equity holders represented."); Marjorie L. Girth, Rethinking Faimess in Bankruptcy Proceedings, 73 AM. BANKR. L.J. 466 (1999) ("[N] egotiations with the goal of proposing a successful reorganization plan are usually carried out between the debtor's representatives and those representing the creditors' committee.").

${ }^{70}$ See 11 U.S.C. $\$ 1126$ (a) (1994) ("The holder of a claim or interest allowed under section 502 of this title may accept or reject a plan."); id. $\$ 1129(\mathrm{a})(7)$, (b) (mandating that for a plan to be confirmed, either all impaired classes must accept it, or the plan must satisfy "cram down" requirements).

${ }^{71}$ If a class of claims or interests is not impaired under the plan, the members of that class "are conclusively presumed to have accepted the plan," and they need not be given an opportunity to vote. Id. $\$ 1126$ (f).

${ }^{72}$ See id. $\$ 1126$ (c) ("A class of claims has accepted a plan if such plan has been accepted by creditors ... that hold at least two-thirds in amount and more than one-half in number of the allowed claims of such class held by creditors ... that have accepted or rejected such plan.").

${ }^{73}$ See id. $\$ 1129$ (a) (7) (stating that each creditor must either accept the plan or "receive or retain under the plan ... property of a value, as of the effective date of the plan, that is not less than the amount that such [creditor] would so receive or retain if the debtor were liquidated under chapter 7 of this title on such date"). This guarantee of receipt in Chapter 11 of at least the amount of the liquidation dividend is known as the "best interests of creditors" or simply the "best interests" test. See TABB, supra note 
of creditors as a whole is overridden and the plan is crammed down on them, the Code assures them fair treatment in relation to the other classes of creditors and interest holders. ${ }^{74}$ Thus, the Bankruptcy Code contains a package of protections-both procedural and substantivefor the creditors who do not participate directly in the proceedings by serving on a creditors' committee. ${ }^{75}$

Although these built-in protections may be sufficient to satisfy due process concerns in traditional bankruptcy cases, ${ }^{76}$ the complexities and innovations usually found in mass tort bankruptcies may render these protections less effective in that context. For example, a bankruptcy class of tort claimants may consist of hundreds of thousands of persons with a variety of injuries, whether manifested or merely poten-

20 , at 841 ("The best interests test of $\S 1129(\mathrm{a})(7)$ is intended to provide a floor of protection for dissenting members of a class.").

${ }^{74}$ See 11 U.S.C. § 1129(b)(1) (1994) (stating that to be confirmed by cram-down method, a plan must not "discriminate unfairly" and must be "fair and equitable" with respect to each impaired class that has not accepted the plan). In the case of a class of unsecured creditors, the fair and equitable test incorporates the absolute priority rule pursuant to which no creditors or security interest holders junior to the class of unsecured creditors may receive any property under the plan if the unsecured creditors are not paid in full. See id. at $\$ 1129$ (b) (2)(B).

${ }_{75}$ Because of the opportunity for direct voting in bankruptcy, the need for precise definition of classes to eliminate all conflicts of interest is arguably lessened. Claimants are permitted to speak for themselves, rather than having decisions made for them by representatives. Because some claimants can be outvoted, however, the Bankruptcy Code provides substantive protections to assure fair treatment. See id. $\$ 1129$ (a)(7), (b). The Court in Amchem held that a court's approval of a class action settlement as fair cannot substitute for satisfaction of the class certification requirements. See Amchem Prods., Inc. v. Windsor, 521 U.S. 591, 621 (1997) (stating that Rule 23(e)'s "prescription was designed to function as an additional requirement, not as a superseding direction, for the 'class action' to which Rule 23(e) refers is one qualified for certification under Rule 23(a) and (b)"). Likewise, in bankruptcy the substantive protections of the best interests test and the absolute priority rule do not supersede the voting and classification requirements. Both aspects, procedural and substantive, are necessary to protect creditors' interests.

${ }^{76}$ See In re Dow Corning Corp., 244 B.R. 634, 665 (Bankr. E.D. Mich. 1999) ("[O]ne of Congress' primary motivations for limiting class membership to substantially similar claims was... to ensure 'that the votes cast by the class will reflect the joint interests of the class." (quoting In re Huckabee Auto Co., 33 B.R. 141, 148 (Bankr. N.D. Ga. 1981))); William Blair, Classification of Unsecured Claims in Chapter 11 Reorganization, 58 AM. BANKR. L.J. 197, 228 (1984) ("The chapter 11 rehabilitation objectives assume that negotiation accomplished through democratic decision-making will provide fair treatment if the distribution remains within the parameters of the confirmation requirements." (footnote omitted)). Cf. Meltzer, supra note 47, at 299 ("I contend that a lender's deficiency claim is substantially similar to trade claims, and that, notwithstanding any potential conflicts of interest, the only appropriate interpretation of the Code is to prohibit separate classification of the creditors holding those claims."). 
tial, and with claims of varying degrees of legal strength. ${ }^{77}$ In a class action context, these differences would require the creation of subclasses with independent representation. ${ }^{78}$ My concern is that in this bankruptcy context, the ability of all members of the class to vote on the plan may not sufficiently ensure that the voices of each distinct subgroup will be adequately heard. ${ }^{79}$ A distinct minority-for example, those tort claimants with especially serious injuries and strong cases-might get outvoted by a large number of holders of small claims who favor a quick pay-out of relatively small amounts with little proof required. ${ }^{80}$ Thus, the class as a whole may support a plan that provides for quick pay-outs and puts significant disincentives in the way of achieving more substantial payments, a result not in the interests of the larger tort claimants included in the class. ${ }^{81}$ This possibility is made all the more likely by the frequent practice in mass tort bankruptcies of valuing all claims for voting purposes at one dollar in order to avoid the necessity of individually liquidating each of the thousands of tort claims. ${ }^{82}$ This practice mutes the voice of large tort claimants

7 See, e.g., In re A.H. Robins Co., 880 F.2d 694, 697 (4th Cir. 1989) (describing class of Dalkon Shield claimants as consisting of approximately 195,000 unliquidated personal injury claims); REPORT ON MASS TORT LITIGATION, supra note 2, app. E at 34 (describing the class of asbestos personal injury claims in the Eagle-Picher bankruptcy as consisting of approximately 162,000 claims).

${ }^{78}$ See Ortiz v. Fibreboard Corp., 527 U.S. 815, 119 S. Ct. 2295, 2319-20 (1999) (holding that the differences between present and future claimants, and between those possessing more valuable claims because of potential insurance coverage and those without that possibility, require separate subclasses for each distinct group).

${ }^{79}$ See Bruce A. Markell, Clueless on Classification: Toward Removing Artificial Limits on Chapter 11 Classification, 11 BANKR. DEV. J. 1, 12-13 (1995) ("Behind the assumption that voting is meaningful lies the notion that some common interest exists among the members of a class. Otherwise, it makes little sense to say that anything less than a unanimous vote could bind dissenters."); id. at 16 ("[A] plan proponent has the opportunity, under the right circumstances, to overwhelm objecting parties by including them in a class filled with sympathetic creditors.").

${ }^{80}$ Cf. In re Dow Corning Corp., 244 B.R. at 665 (rejecting the argument that a discrete subgroup within a class of physician claimants was disenfranchised by classification together with a larger group of physician claimants having different interests; so long as the claims are substantially similar, "assertions of attempted vote gerrymandering are simply irrelevant").

${ }^{81}$ See SOBOL, supra note 35, at 328 (arguing that the vote of the class of the Dalkon Shield claimants was "lopsided" because $94 \%$ of the total voting stength would not have filed claims outside of bankruptcy or had only minor injuries, while $6 \%$ had substantial claims); Vairo, supra note 42, at 134-36 (describing various pay-out options under Robins trust, with quickest payouts being for low value claims).

${ }^{82}$ See, e.g., In re A.H. Robins Co., 880 F.2d at 697 ("[F]or purposes of voting, each Dalkon Shield Claim was estimated and allowed to be equal."); Kane v. Johns-Manville Corp., 843 F.2d 636, 646 (2d Cir. 1988) ("[T]he Bankruptcy Court . . 'allowed' [asbestos personal injury] claims for voting purposes in the arbitrary amount of one dol- 
in the voting process.

Once a subgroup of tort claimants is outvoted, the substantive guarantee of the best interests test might provide little protection. In a bankruptcy involving tort claims that have been estimated to amount to hundreds of millions or billions of dollars ${ }^{88}$ - an amount frequently far in excess of the value of the company-the court may quickly conclude that the tort claimants as a whole will receive more under the reorganization plan's trust than they would in a Chapter 7 liquidation. $^{84}$ No comparison will be made between the amount a particular dissenting tort claimant will receive under the plan and the liquidation dividend he or she would receive in Chapter $7,{ }^{85}$ since most tort claims will not have been individually valued at this stage. It is possible, therefore, that the outvoted large tort claimants will not actually receive as much as the Bankruptcy Code supposedly guarantees them.

The inclusion of future claimants within the bankruptcy further complicates the effectiveness of bankruptcy's built-in protections for mass tort claimants. Professor Resnick addresses some of the resulting concerns by endorsing the Bankruptcy Review Commission's proposal for the appointment of a legal representative for future mass tort claimants. ${ }^{86}$ This recommendation would provide firmer statutory authority for the practice that has been followed in a number of mass tort bankruptcies. ${ }^{87}$ Providing a separate legal representative for the

lar ...." (quoting 11 U.S.C. § 502(a) (1994))); REPORT ON MASS TORT LTIIGATION, supra note 2, app. E at 30 ("When it came time to tabulate the votes, each asbestos personal injury and property damages claim, as well as each lead personal injury claim, would be valued at $\$ 1.00 .^{\prime \prime}$ ).

${ }^{2}$ See, e.g., In re A.H. Robins Co., 880 F.2d at 699 (noting that the district court valued Dalkon Shield claims at $\$ 2.475$ billion); REPORT ON MASS TORT LITIGATION, supra note 2, app. $\mathbf{E}$ at 30 (noting that the bankruptcy court estimated present and future asbestos claims at $\$ 2.5$ billion; as a result of a compromise with the unsecured creditors' committee, the valuation was reduced to $\$ 2$ billion).

${ }^{2}$ See, e.g., In re A.H. Robins Co., 880 F.2d at $698-700$ (indicating that the Fourth Circuit rejects a challenge to the confirmation of the Robins reorganization plan based on the best interests test, and examining only the basis for the district court's estimation of value of Dalkon Shield claims); In re Eagle-Picher Indus., Inc., 203 B.R. 256, 275 (S.D. Ohio 1996) (concluding, with little discussion, that given the inclusion of future asbestos claims within the bankruptcy proceeding, the best interests test is satisfied); SOBOL, supra note 35, at 238-43 (criticizing application of the best interests test in Robins bankruptcy).

${ }^{85}$ See, e.g., sources cited supra note 73 (explaining the best interests test).

${ }^{86}$ See Resnick, supra note 4, Part II.B

${ }^{87}$ See, e.g., In re A.H. Robins Co., 88 B.R. 742, 744 (Bankr. E.D. Va. 1988), affd, 880 F.2d 694 (4th Gir. 1989) (listing a "Future Claimants' Representative" among the "official committees" appointed in the case); In re UNR Indus., Inc., 46 B.R. 671, 674 (Bankr. N.D. Ill. 1985) (authorizing appointment of a legal representative for "putative asbestos disease victims"); REPORT ON MASS TORT LITIGATION, supra note 2, app. E at 
future claimants also addresses the concerns expressed by the Supreme Court in Amchem and Ortiz about the inadequacy of representation due to conflicts of interest between claimants with present injuries and those whose injuries have not yet manifested. ${ }^{88}$ Experience to date shows that future claims' representatives can provide an independent voice for the interests of the unknown future claimants. This independent voice counterbalances the advocacy by other creditors' committees, including any tort claimants' committee that is appointed and that might be presumed primarily to represent the interests of present claimants. ${ }^{89}$

Although the conflict of interest problem can be reduced by the participation of a future claims' representative, other concerns remain. Most future claimants are unable to participate directly in the bankruptcy case because their identities will not be known until some future, post-bankruptcy date. Thus, even if the rights of present tort claimants are adequately protected by their opportunity to vote to accept or reject the reorganization plan and by the provision of substantive protections for them if they are outvoted, future claimants' rights are exclusively in the hands of their representative. That representative will not only negotiate on the future claimants' behalf, but she will also vote on the plan for them and will raise any objections to confirmation on their behalf. ${ }^{90}$ In this instance bankruptcy becomes a representational suit, like a class action, rather than a special remedial scheme with its own built-in protections. Any statutory authorization for the appointment of a future claims' representative therefore needs to take account of the due process and fairness concerns raised with respect to binding absent parties to the results of representational

39 (discussing appointment of a "legal representative for future personal injury and property damage claimants" in asbestos bankruptcy).

${ }^{83}$ See Ortiz v. Fibreboard Corp., 527 U.S. 815, 119 S. Ct. 2295, 2319-20 (1999) ("[I]t is obvious after Amchem that a class divided between holders of present and future claims (some of the latter involving no physical injury and to claimants not yet born) requires subdivision into homogeneous subclasses ...., with separate representation to eliminate conflicting interests of counsel."); Amchem Prods., Inc. v. Windsor, 521 U.S. 591, 626 (1997) ("[F]or the currently injured, the critical goal is generous immediate payments. That goal tugs against the interest of exposure-only plaintiffs in ensuring an ample, inflation-protected fund for the future.").

${ }_{89}^{8}$ See, e.g., REPORT ON MASS TORT LITIGATION, supra note 2, app. E at 39-40 (discussing independent role played by future claims' representative in asbestos bankruptcy); SOBOL, supra note 35, at 222-23 (discussing future claims' representative's opposition to reorganization plans that did not adequately protect the rights of future Dalkon Shield claimants).

${ }^{90}$ See, e.g., NATIONAL BANKR. REVIEW COMM'N, BANKRUPTCY: THE NEXT TWENTY YEARS 329-30 (1997) (recommending the appointment of a mass future claims representative). 
suits, ${ }^{91}$ even if bankruptcy generally is freed of those requirements. While the Bankruptcy Review Commission wisely suggests that some mass tort bankruptcies may require the appointment of multiple future claims' representatives, ${ }^{92}$ the experience to date has been that only one person is appointed to represent all future tort claimants in the case. ${ }^{93}$ Amchem and Ortiz cast doubt on the legitimacy of such a monolithic representation of future claimants.

Professor Resnick and other commentators have argued that the appointment of a future claims' representative, coupled with the provision of constructive notice, will satisfy any procedural due process concerns about the inclusion of future claimants in a mass tort bankruptcy. ${ }^{94}$ Professor Resnick himself notes, however, that the Supreme Court in Amchem raised questions about the efficacy of notice to persons who "may not even know of their exposure, or realize the extent of the harm they may incur., ${ }^{95}$ Although the Court found no need to rule definitively on this point, it did pointedly question whether "notice sufficient under the Constitution ... could ever be given to legions so unselfconscious and amorphous. ${ }^{, 96}$ Given that statement, one might question whether the Supreme Court will view constructive notice as providing much protection for future claimants in bankruptcy. ${ }^{97}$ If not, the Court may be unwilling to allow future claimants

${ }^{91}$ See Jones, supra note 55, at 1722 ("[A] collective remedy is a collective remedy, whether enforced in a class action or bankruptcy, and the criteria necessary to protect absentee class members' rights should not in principle vary depending on the forum.").

92 See NATIONAI BANKR. REVIEW COMM'N, supra note 90, at 332 ("Each class of mass future claimholders would be entitled to its own representative, as the interests of the classes of mass future claims may be adverse to one another.").

${ }_{93}$ See, e.g., sources cited supra note 87 (listing cases in which a single individual was appointed to represent the interests of future tort claimants).

${ }_{94}$ See Resnick, supra note 4, Part II.B (noting how appointment of a future claimants' representative and constructive notice meets any due process concerns); see also Kathryn R. Heidt, Future Claims in Bankmuptcy: The NBC Amendments Do Not Go Far Enough, 69 AM. BANKR. L.J. 515, 515 (1995) ("Any due process problems resulting from insufficient notice or knowledge can be addressed by appointing a representative for the future claimants and establishing a fund to pay the claimants as their claims become fixed."); Ralph R. Mabey \& Jamie Andra Gavrin, Constitutional Limitations on the Discharge of Future Claims in Bankruptcy, 44 S.C. L. REv. 745, 781 (1993) ("The... mandate of Mullane therefore usually requires the opportunity for future claimants to be heard through a representative when publication notice to them is largely futile.").

${ }_{95}$ Amchem Prods., Inc. v. Windsor, 521 U.S. 591, 628 (1997).

${ }^{96}$ Id.

${ }^{97}$ An argument can be made that in many bankruptcy cases, effective notice can be given to persons who are in the population of those expected to incur claims against 
to be bound by a reorganization plan confirmed in a bankruptcy case in which their interests were litigated by an appointed representative unless great care was given to ensuring the absence of conflicting interests within the group represented by each future claims' representative.

\section{CONCLUSION}

Professor Resnick has stated well the advantages of utilizing bankruptcy as a vehicle for resolving mass torts. Bankruptcy has many procedural and conceptual features that can be applied to permit a resolution of all of the claims facing a beleaguered mass tort defendant. My enthusiasm for a bankruptcy solution, however, is tempered by the recognition of the concerns expressed by the Supreme Court in other mass tort contexts about forcing a judicial resolution on claimants who are not active participants in the lawsuit leading to the global solution. Perhaps bankruptcy is sufficiently distinguishable from class actions that the Supreme Court will eventually approve it as a mass tort device. As other options disappear or become less attractive, it may become one of the few remaining possibilities. To date, however, the Court has not shown itself to be pragmatic in its approach to the judicial resolution of mass torts. ${ }^{98}$ As a result, although a bankruptcy

the debtor in the future. In the asbestos bankruptcies, for example, extensive efforts have been made to provide notice by means of publications directed at unions and organizations of workers in industries that involved exposure to asbestos, as well as notice to attorneys handling such cases and widespread notice in general circulation publications. See, e.g., REPORT ON MASS TORT LITIGATION, supra note 2, app. E at 42 (describing extensive notice of bar date given in Eagle-Picher bankruptcy).

Although such announcements may be ignored by many who presently suffer no illness, perhaps it is reasonable to expect that enough persons who know that they have been exposed to asbestos will see the notices that the actions of the future claims' representative can thereby be effectively monitored. Moreover, when these future claimants' injuries do manifest themselves, they will still have the opportunity to liquidate their claims pursuant to the trust or administrative mechanism that is established under the reorganization plan. Even if the "practicalities and peculiarities" of a mass tort bankruptcy case, Mullane v. Central Hanover Bank \& Trust Co., 339 U.S. 306, 314 (1950), justify the provision of constructive notice to such future claimants, I fear that it pushes the limits of due process too far to include within the group of future claimants persons who, at the time of bankruptcy, have not been exposed to the offending product. It cannot even be pretended that someone who has not yet purchased, used, or come in contact with a product that precipitates a mass tort bankruptcy will have any reason to understand that the bankruptcy might affect her rights.

${ }^{98}$ See Ortiz v. Fibreboard Corp., 527 U.S. 815, 119 S. Ct. 2295, 2325 (1999) (Breyer, J., dissenting):

I cannot easily find a legal answer to the problems this case raises by referring, as does the majority, to "our deep-rooted historic tradition that everyone should have his own day in court." Instead, in these circumstances, I believe 
believer, I remain chary about predicting the ultimate triumph of bankruptcy as a mass tort vehicle.

our Court should allow a district court full authority to exercise every bit of discretionary power that the law provides.

Id. (citation and internal quotation omitted); see also Amchem, 521 U.S. at 629 (Breyer, J., dissenting) ("I believe that the need for settlement in this mass tort case, with hundreds of thousands of lawsuits, is greater than the Court's opinion suggests."). 
* $* * * * * *$ 